\title{
The Securitization of the Tri-Border Area between Argentina, Brazil and Paraguay
}

\section{Isabelle Christine Somma de Castro*}

\begin{abstract}
The purpose of this study is to identify the main features of the US discourse regarding the Tri-Border Area between Argentina, Brazil, and Paraguay through the analysis of 16 editions of the Patterns of Global Terrorism and of the Country Reports on Terrorism published from 2001-2016. Securitization theory is applied to explain the use of speech acts as movements to securitize the region. After employing NVivo to measure the frequency of words, a strong link between the rise of the financial semantic field and clashes in the Middle East were observed. The fact that the reports had a special emphasis regarding legislation on terrorism in the three countries was also detected.
\end{abstract}

Keywords: Tri-Border Area; securitization; content analysis; terrorism; George W. Bush; Barack Obama.

\section{Introduction}

In the last decades, the border region between Brazil, Argentina and Paraguay, internationally known as the Tri-Border Area, has been acknowledged as a hub for terrorist activities and financing. Claims of illegal activities were published in governmental and think tank reports as well as in several academic studies and press articles. However, the existing accounts frequently fail to indicate the contradiction between the accusations and the evidence. Assuming that the construction of the demand for security is made through discourse, an analysis of the sources which sustain that demand is imperative to understand how the region has been represented to the public, and the impacts thereof.

One of the most notorious and influential reports that addresses terrorist acts and groups is published annually by the US Department of State. The reports Patterns of Global Terrorism (published between 2001-2004) and Country Reports on Terrorism (published between 2005-2016) are valuable portraits of the George W. Bush and Barack H. Obama administration's views concerning terrorism and counterterrorism. Both series of documents reveal an emphasis on specific issues and episodes, which may or may not

\footnotetext{
* University of São Paulo (USP), São Paulo-SP, Brazil; isasomma@hotmail.com. ORCID iD 0000-0002-35724565 .
} 
be related to the Tri-Border Area. Understanding how the region is portrayed in official records may help disclose the concerns of US administrations regarding Argentina, Brazil, and Paraguay, as well as their specific demands related to security.

This study is based on the idea that security frequently takes politics beyond rules and that it may also be framed above politics. The concept of securitization, which is seen as a more extreme version of politization, is helpful to understand how this works (Buzan, Waever and de Wilde 1998: 23). The theory offers effective means to understand how the idea of threat originates, how enemies are constructed in discourse, and how specific actors use it in their favour and against other actors. The securitization approach may also be useful in disclosing flaws in political discussions about the need of security and to challenge the use or misuse of this concept. As a result, this approach can improve the search for possible explanations of the securitizing actors' actions.

Securitization involves three dimensions, as claimed by Buzan, Waever and de Wilde. The first dimension is the 'speech act', in which the understanding of a given threat is constructed. The securitizing actor, that accounts for the second dimension of the theory, can demand exceptional measures to deal with the specific threat. These measures are urged by the speech act elaborated by the securitizing actor to persuade an audience to accept the measures, constituting the third dimension. The effort to have the audience agreement is a 'securitization movement' that can only be successful if the audience is convinced that there is an existential threat and that this threat needs to be tackled with 'special measures and justifying actions outside the normal bounds of political procedure' (Buzan, Waever and de Wilde 1998: 24).

Reports such as Patterns of Global Terrorism and Country Reports on Terrorism are powerful tools that can drive securitization movements because they are public documents made exactly to disclose views, requests, and claims made by the US Department of State, an important agency of the securitizing actor. Although the reports are influential to public opinion, it is difficult to measure their impact on audiences. As argued by Stritzer (2007: 363), it is not clear which audience the authors are referring to, what are the implications of the existence of so many audiences and when exactly the audience should or would be persuaded. This case study does not measure the impact of the documents on the public opinion, but assumes that there is a tension between the main securitization actor, the US administration, and the local governments, especially the Brazilian one, which has been denying the existence of terrorist activities in the region for the past two decades (Castro 2020).

According to Stritzer, another limitation of the securitization approach is its suggestion that there are two centres of gravity which are still 'theoretically underdeveloped' and that probably reflect two different views of the subject. The first view, that he defines as 'internalist', considers the performativity of the speech acts. The second is the 'externalist' one, which comprehends the social process of securitization involving actors and audiences. Stritzer argues that just one of these centres of gravity should be employed and chooses the externalist perspective to be the focus. In his opinion, security articulations have to relate to broader discursive contexts, since the actors gain their power from them (Stritzer 
2007: 362, 367). This study encompasses the two, based on the belief that both the broad context as well as the discursive practice may be disclosed as they are interconnected.

On the internalist view, Amaral (2010) offers probably the most comprehensive empirical analysis of the securitization of the Tri-Border Area. His aim is to investigate how the area entered in the US security agenda, with special focus on the Bush administration. Even though it takes on an unsystematic approach, his research analysed documents from many US government departments. Amaral suggests that the target of the security discourse encompassed two audiences. The first one included the governments of Argentina, Brazil and Paraguay, that did not accept the assumption that there was a nexus between crime and terror in the area. The second, formed by the US Congress and by US government agencies, thoroughly endorsed the existence of such nexus. Although the three South American countries had restrictions to the claims, they nevertheless accepted unusual measures such as including the USA in the ' $3+1$ Group on Tri-Border Area Security.' The research concluded that the securitization movement was partially successful to the first audience and successful to the second one (Amaral 2010: 256-258).

This study aims to identify the main US discourse features about this important frontier through 16 editions of the Patterns of Global Terrorism and the Country Reports on Terrorism. It addresses the possible motivations behind the movements of securitization observed in the Department of State reports. At first, it suggests a special focus on the relationship between the local Tri-Border Arab community as well as Lebanon and Iran, causing the US view on the area to be more related to the conflicts between this country and state and non-state actors from the Middle East. This perception places the local dynamics, such as the increase or the decrease of crime statistics in the region, in a lower level of importance.

Studies have shown that the transnational organized crimes have become more complex in the border and that the militarization response deployed by local governments has been ineffective (Devia-Garzon and Ortega-Avellaneda 2019: 11). Crimes such as smuggling, embezzlement, drugs and arms trafficking, tax evasion, and counterfeiting are common in the area. On the other hand, the tension levels between Washington and groups like Hamas and Hizballah, as well as Tehran, rather than what is actually taking place on the ground, seems to be the focal point of the accusations related to terrorist practices in the Tri-Border Area observed in the documents released by the US Department of State.

This study does not dismiss other catalysts for the discursive pressure exercised by the US Department of State's upon local governments to apply repressive measures on money laundering. It is not possible to ignore other factors, which may have influenced a possible increase in the awareness of the region, such as the Brazilian nuclear program (Wikileaks 2009), the rise of progressive governments in the region - such as the former Paraguayan president Fernando Lugo, who was elected in 2008 and impeached in 2012 as a result of an uncommon brief process in Congress, the lack of regional support for the war on terrorism (Halliday 2002: 237), and the rapprochement between Brazil and Iran through the 2010 tentative Nuclear Agreement negotiated between the two countries and Turkey. Moreover, it is also worth mentioning longstanding known US interests in the region, for 
instance, regarding the Guarani Aquifer, the second-biggest underground waters supplier in the world, and the project to install a US military base in Paraguay (Jorge 2009: 86). Although several issues have been responsible for the rising attention devoted to the TriBorder Area, this paper argues that the Middle East dynamics are the main catalyst for establishing a nexus between the region's illegal activities and terrorism.

The goal of this investigation is to increase the knowledge of these documents by adding empirical data to support a more qualified examination of the US counterterrorism tactics regarding South America. The approach taken by the research is a hybrid methodology through the use of the software NVivo. Adopting this tool of analysis enabled the measurement of the frequency of words related to the Tri-Border Area and to the borders of its neighbouring countries - namely Argentina, Brazil, and Paraguay - in a corpus of 16 reports. Four of these are editions of the report Patterns of Global Terrorism, which relate to the years 2000-2003, and 12 are editions of the Country Reports on Terrorism that refer to 2004-2015. The dates of the documents reflect the year of reference and not that of the publication, which is the following year ${ }^{1}$. These editions were released during George W. Bush's administration, throughout the period from January 2001 to January 2009, and during Barack H. Obama's presidency, from January 2009 to January 2017. Both presidents were re-elected for a second term.

This article is divided into three sections. In the first section, the historical background of the supposed link between the Tri-Border Area Muslim community and international terrorism is briefly described. This includes a discussion of the security implications of the unproven relation of the Buenos Aires bombings in the 1990s to the area, as well as renewed claims of the existence of terrorist groups in the frontier following the September $11^{\text {th }}$ terrorist attacks. In the second section, the methodology is explained, namely how the corpus was classified, why the NVivo software was chosen and in what ways observing the frequency of words is useful to identify patterns. The results are also presented and discussed. In the last section, the main conclusions of the study are addressed.

\section{The Tri-Border Area and terrorism}

The literature on the Tri-Border Area has highlighted that the assumption of a supposed presence of terrorists in the region originated after the Buenos Aires bombings in 1992 and 1994 (Rabossi 2004; Pinto 2016; Nasser 2018: 136). Since then, governmental reports and media outlets have speculated about how criminal and financial offenses such as drug trafficking, money laundering and smuggling in the region might be financing the activities of terrorist groups like Hamas and Hizballah².

The cities of Foz do Iguaçu, in Brazil, Ciudad del Este, in Paraguay, and Puerto Iguazu, in Argentina, are divided by two rivers, Paraná and Iguaçu. These political and geographic limits did not have any specific denomination before March 1996. Only from then on, the governments of the three countries began to refer to that specific area as a 'Tríplice Fronteira' or 'Triple Frontera' (Rabossi 2004: 24). The newly attributed designation would be used not only in official documents but also in academic studies and by the press. The 
1996 edition of the Patterns of Global Terrorism, translated into English in quotes, lowercase and no hyphen, inserted under the Argentina title: “'triborder” area, was also introduced by the US Department of State at the time. In this particular document, the term was linked to new security measures that were being implemented by the governments of the three countries 'to help address the growing security concerns' (Department of State [USA] 1997). Brazil was not placed under a specific entry in this edition.

From a geographic landmark, this frontier became 'a category built by diplomatic agreements, by the actions of national and international security agencies' and also by international media outlets (Pinto and Montenegro 2008: 5). The new designation for the region was created to answer demands for security, and more specifically, regarding intra-national and transnational dynamics (Amaral 2010: 33). Although Brazil has nine tri-borders, only this one can be found in as a title case in official documents and press articles without any other clarification. The term was created and is still being used as a constructed securitized form of the region, leaving its other known characteristics, such as the fact that it is an ecological paradise and a tourist attraction, aside. The presence of a large Arab and Muslim community mainly from the Bekaa Valley and South Lebanon, but also of Palestinians, Syrians, Jordanians, and Egyptians, probably made the region a place of greater awareness to securitizing actors.

The region has been referred to as a security threat since two deadly terrorist attacks hit Buenos Aires in the 1990s. The first one targeted the Israeli embassy in 1992 and the second, the most lethal one, destroyed the Asociación Mutuales Israelitas Argentinas (AMIA), a Jewish community centre, in 1994. Both bombings killed 115 people, injured hundreds of people who lived and worked in the neighbourhood and destroyed many buildings nearby. A Buenos Aires criminal court charged 12 Iranian nationals and one Lebanese citizen believed to be a Hizballah operative (Department of State [USA] 2004) for the latter attack. High ranking Argentine authorities, such as the former president Carlos Menem, were accused of forgery and covering up.

The link between the AMIA bombing and the Tri-Border Area was made public by the Interior Minister of Argentina Carlos Corach two years after the last bombing, perhaps as a way to dismiss the accusations that the government was not doing enough to solve the case (Ministry of Foreign Affairs [Brazil] 2001). Corach argued that the explosives used in at least one of the attacks were smuggled through Argentina by the Brazilian border between Foz do Iguaçu and Puerto Iguazu. The charge was renewed more recently, in 2015, with a new allegation. The Argentinian chief prosecutor, Alberto Nisman, filed a complaint in January 2015, ${ }^{3}$ accusing the government of President Cristina de Kirchner of conceiving a criminal plan to grant immunity to Iranian officials accused of participating in the Buenos Aires blasts. ${ }^{4}$ The report also reveals details of the investigation concerning both attacks. The Tri-Border Area is mentioned in terms of telephone calls made by a Colombian national, Samuel Salman El Reda - one of the supposed protagonists in the AMIA bombing - to a cell phone in Foz do Iguaçu registered in the name of André Marques. These calls are the only connection made in the report between the attack and the border area. 
The fact that both the first and the last call recorded were made from the two respective airports leads us to conclude that he [El Reda] had informed the active Hezbollah member working as André Marques about both the arrival and departure of members of the task force that carried out the final stage of the mission (Nisman 2015: 156).

One year after the prosecutor's complaint was made public, the Colombian government revealed that El Reda's passport was fraudulent (Kollmann 2016). Since then, the identity of the real key agent of the plot remains unknown. Although El Reda's identity is uncertain, Interpol (2009) issued in 2009 an international arrest warrant against him on its website, after a request made by Nisman in 2006. The identity of Andre Marques was not established; neither was it even confirmed if he existed. Not a single person who lives or lived in the Tri-Border Area has been indicted or identified as a suspect in either of the deadly attacks for more than two decades following it.

The culprits of the crimes, as before mentioned, are suspected to be agents designated under the government of the Islamic Republic of Iran, and a member of Hizballah, a Shia militant group from Lebanon that is also financed by the Iranian regime. These Lebanese and Iranian nationals, with no connections with the Tri-Border Area, were indicted by the Argentinian Courts and included in the Interpol list of most wanted persons for terrorism. One of these suspects is Mohsen Rabbani, who worked as an official at the Iranian Embassy in Buenos Aires and now lives in Qom, Iran. Rabbani was interviewed by a Brazilian journalist and denied all the accusations regarding having helped to organize the plot that killed almost 100 people in the AMIA attack of 1994 (Adghirni 2012).

Although many suspects were indicted in Argentina, the case is far from being closed. The 'local connection' - as a group of Argentinian citizens involved with the plot is known - is still under investigation and awaiting criminal proceedings. The involvement of Argentinian police members and of the Secretaría de Inteligencia del Estado (SIDE) ${ }^{5}$, the country's secret service, in the AMIA attacks has not been fully dismissed (Davies 2015; Caballero 2005; Salinas 1997; Sanz e Paolella 2007). In a recent trial, an Argentinian federal judge, Juan José Galeano, and a former chief of SIDE, Hugo Anzorreguy, were convicted of organizing a cover-up operation and sentenced to six and four and a half years in prison, respectively. Conversely, former Argentinian president Carlos Menem was found not guilty in this plot. Another famous character of the 'local connection, Carlos Telleldín, who faced trial and was found not guilty (Nisman 2015: 157), was sent back to court in 2019 , convicted of obstruction of justice and sentenced to three years in prison. He will be tried again for his involvement in the AMIA bombing (Tomás 2019).

A similar case in 1970 had the same characteristics but a different outcome. Two gunmen invaded the Israeli Embassy in the Paraguayan capital, Asuncion, killing one person and injuring another. Soon thereafter, the Brazilian newspaper O Estado de S. Paulo published an article relating the Arab residents of Foz do Iguaçu with the action. After arresting the two offenders, both Palestinians who had come from the United Kingdom, the Paraguayan Justice found no evidence of the involvement of the Tri-Border Arab community with the raid (Karam 2013: 60). New evidence has shown that the two assailants 
did not plan the attack and were trying to receive a stipend promised by the Israeli government to Palestinians who accepted to settle in Paraguay (Rivarola 2020).

The fluidity of the frontier, where thousands of people and products cross over the two bridges between Foz do Iguaçu and Ciudad del Este and between Foz do Iguaçu and Puerto Iguazu in a daily basis, is a security concern for the three countries. As with other borders, crimes such as drugs and arms trafficking, smuggling, and other illicit activities are a common issue. What is uncommon, however, is to associate these activities to terrorism financing in South America. For the past decades, there has been a discourse not only linking such activities in the region with international terrorism but also connecting both the Shia and Sunni Muslim communities from the Tri-Border Area to terrorism financing around the globe.

After the September $11^{\text {th }}$ attacks, a link between the Tri-Border Area and terrorist activities remerged. The connection was made by the US Department of State, which suggested that the area hosted training camps and financed international groups accused of terrorist acts, identifying it as a 'safe haven' for terrorists (Amaral 2010; Folch 2012; Ferreira 2016). The visit of Khalid Sheikh Mohammed to Foz do Iguaçu in 1995, one of the most well-known members of Al Qaeda who had involvement in the World Trade Center attack in 1993, supported the allegation that the group had links with the community in the region (CNN 2003). On the other hand, the information published in the Brazilian magazine Veja about a supposed Osama bin Laden's trip to the area has been found untrue (Policarpo Junior 2003; Benson 2003).

The suspicions of an association between the local Arab community and Al Qaeda were dropped after the release, on July 2004, of the final report provided by an independent and bipartisan commission created by the U.S. Congress to investigate the circumstances of the September $11^{\text {th }}$ attacks. The 9/11 Commission Report recognizes that 'No clear evidence connects him [Sheikh Mohamed] to terrorist activities in those locations' 6 (National Commission 2004: 148). It is fair to say that following the publication of this investigation in 2004, the Arab community in the Tri-Border was acquitted of having any relationship to terrorists and to the perpetrators of 9/11 and the 1993 World Trade Centre attacks.

Much of the literature produced by local experts since the mid-2000's also emphasizes the inconsistent and contradictory claims regarding the Tri-Border Area. Costa and Schulmeister (2007: 34) describe the lack of evidence of the nexus crime-terrorism and argue that the remittances sent abroad by the Middle Eastern immigrants do not validate the claim that they fund terrorists. Ferreira (2016: 213) has shown how contradictory the US Department of State view is. While claiming the presence of terrorism financers in the region, the reports of this agency also stressed the lack of evidence to prove it. What is not yet clear is the impact of these allegations and why they are still being made to this day. The analysis of 16 editions of the US Department of State reports may improve our understanding of the reasons why the Tri-Border Area has been continuously linked to the terrorist threat. 


\section{Content analysis}

This section will explain why the sample was chosen, how it was categorized, how the method was used and the main findings of the analysis. As described earlier, this article aims to examine the US Government discourse on terrorism in Brazil, Argentina and Paraguay after September $11^{\text {th }}$ during the George W. Bush administration until the end of Barack Obama's in 2016. In order to achieve this goal, a selection of documents that had least the same patterns was required. Most importantly, these documents had to be similar in purpose and size during both administrations to make the comparison reliable.

The US Secretary of State is requested by law to provide to the Congress a 'full and complete annual report on terrorism for these countries and groups meeting the criteria of the act,' as established by the US Code in compliance to (A), (B) and (C) of the section 2656f(a) of Title 22 (Department of State [USA] 2004: 1). The report should include the activities of individuals, terrorist organizations or umbrella groups in the previous year, as well as detailed assessments of terrorist acts that occurred in other countries. However, the documents are more detailed than required by law (Department of State [USA] 2001).

The most well-known of these reports are both Patterns of Global Terrorism, published until 2005, and Country Reports on Terrorism, the renewed version of the previous publication with a few variations. They are a reliable option to analyse how the US Department of State summarizes information about terrorism and what main suggestions are made to tackle the problem. The first report that dealt with this demand was the Patterns of Global Terrorism, released for the first time in 1997 during President Bill Clinton administration (1993-2001). Four editions of this series of reports were included in this study, referring to the years $2000^{7}, 2001,2002$ and 2003, published during Bush's administration. All four contain specific chapters about Latin America and just one has a subsection dedicated to the region, entitled 'Tri-Border's. The information about the three countries that share the border (Argentina, Brazil, and Paraguay) could only be found in this section.

The 2004 report, released in April 2005 during the second term of President Bush, had its name and format changed. The configuration of the Patterns of Global Terrorism content and methodological approach was criticized. Since then, the most important document about international terrorism and counterterrorism published by the US Government became the Country Reports on Terrorism. Its first edition was more concise than the previous one. The new report had only 132 pages, while the average number of pages of the Patterns of Global Terrorism editions was 200.

The 2005 edition, released on April 2006, has a new chapter, the third, entitled 'Terrorist Safe Havens', that includes a subsection about the Tri-Border Area. The fifth chapter, 'Country Reports: Western Hemisphere', created sections for each country, including Argentina, Brazil and Paraguay. Since the release of this edition, the Tri-Border Area is officially considered a safe retreat/sanctuary/shelter for terrorism by the US Department of State, which constitutes a way to label the region as a threat to the world. The following passage makes a very clear association of the local Muslim community with groups considered by the US Department of State as terrorists: 


\section{The Triborder Area}

Suspected supporters of Islamic terrorist groups, including Hizballah and HAMAS, take advantage of loosely regulated territory and proximity to Muslim communities in Ciudad del Este, Paraguay, and Foz do Iguacu [sic], Brazil, to engage in illegal activity and illicit fundraising (Department of State [USA] 2006: 23).

In another edition, the relationship between the area and terrorism is more extensively portrayed. In the 2008 Country Reports on Terrorism (CRT), released in April 2009, the Tri-Border Area is also described in a new section of the 'Terrorist Safe Havens' chapter, titled 'Strategies, tactics, tools for disrupting or eliminating 'safe havens.' It is informed that the US 'remained concerned' that both Hizballah and Hamas 'were raising funds in the TBA by participating in illicit activities and soliciting donations from sympathizers within the sizable Muslim communities in the region'. However, the report admits that there was no 'corroborating information' about the presence of operatives of any 'Islamist extremist groups' in the Tri-Border Area, which itself is a contradiction to the statement that the region is a safe haven to terrorism (Department of State [USA] 2009: 214). Previous research on this issue had shown that the lack of empirical research in the region and the prejudice against the Muslim and Arab community spread this misconceived belief (Ferreira 2009: 183).

The Tri-Border Area remained in the safe havens list published in the CRT editions of 2009, 2010 and 2011. The list also included countries like Somalia and Afghanistan, where armed militias and gangs operate freely, something that was not seen in and around the Tri-Border Area. Another major inconsistency is not mentioning as a safe haven the area where the Fuerzas Armadas Revolucionarias de Colombia (FARC) used to rule until the signature of the 2017 peace agreements (Castro, 2015: 16-17). The Tri-Border Area disappeared from the 'Terrorist Safe Havens' chapter list of the 2012 Country Reports on Terrorism (CRT), released in May 2013. In this edition, the only countries of South America mentioned are Colombia and Venezuela - in addition to the FARC - in chapter 2, 'Western Hemisphere Overview' (Department of State [USA] 2013: 210). The report does not explain the reasons for excluding the Tri-Border Area from the list, where it had been placed since 2005 .

Considering the representative nature of the documents, 16 were chosen, referring to the years between 2000 and 2015 and published in the following years, 2001 and 2016. To isolate only what was written about the three focal countries, that is, only the excerpts of the reports that had as titles the words Argentina, Brazil, Paraguay, and Tri-Border Area, accounting for the border between them, were added to the corpus. All the excerpts collected in each report were aggregated in one single segment and identified by the year of publication. As a result, the final corpus consisted of a total of 16 segments, each representing one year, between the years of 2000 and 2007, published during Bush's administration (2001-2008), and 2008 and 2015, during Obama's (2009-2016). Therefore, 
the corpus consists of Patterns of Global Terrorism (PGT) reports from 2000 to 2005 and of CRT reports that refer to the period between 2006 and 2015.

Hybrid methods that encompass qualitative and quantitative tools can offer an effective approach to analyse this corpus. Observing a list of most frequently used words is helpful not only to identify patterns and differences between each segment, but also between the two administrations. NVivo, the chosen software, is one of the most well-known and widely adopted tools for this purpose. The selection of this software is due to its reliability and validity. Besides, the aim of this study is also to investigate which subjects are associated with all three countries and the border, which can also be achieved by counting the frequency of words used in the reports.

Before running the software, words with three or fewer letters were excluded from the analysis. Later, function words like 'again,' and 'this' were also ignored, as they would not add useful information about the subject. Each year's excerpts were analysed independently by the software; the results from the most frequently used words to the least used words were inserted in a column. The next step was to divide these words into two different tables, referring to one of the two administrations, namely the results from the years 2000 to 2007, corresponding to Bush's years in office (2001-2007), and from 2008 to 2015, relating to the Obama's administration (2008-2016).

Some of the findings were already expected. The words 'Paraguay, 'Brazil' and 'Argentina' were among the five most frequent words of the whole corpus. These three words are the names of the countries selected for this study and were also used by the authors of the documents to name the sections of the excerpts. Consequently, these words are not considered in the analysis. That is why the most common word detected in the reports of both administrations is 'terrorist.' This word was used 92 times during the eight years of Bush administration excerpts and 190 times in the same number of excerpts of the Obama administration. The latter used the word 'terrorist' more than twice in comparison with the previous one, which can be considered an unexpected finding, as the Democrat president promised to leave the War on Terror rhetoric behind. However, this finding is aligned with other works that indicate that Obama had, in fact, restored the previous rhetoric concerning terrorism (McCrisken 2011). The other five most frequently employed words by Bush's reports were 'terrorism' (73 times), 'government' (62), 'money' (61), 'laundering' and 'united' (56 each), as can be seen in Figure 1 (below) and Table 2 (see Appendix). During Obama's administration, the following top words were: 'border' (142 times), 'financial' and 'security' (126 each), 'money' (121) and 'enforcement' (119), as illustrated in Figure 2 (below) and Table 4 (see Appendix).

From a broader perspective, it was possible to identify the most common semantic field in all excerpts, notably during the Obama administration: the financial one. This field deals more specifically with terrorism financing. It may indicate that both administrations were focusing their attention on crimes in the region related to this field. Besides, it seems that there is an effort to make a connection between financial crimes and terrorism as the primary focus of these documents is reporting about the latter subject. The most used words in this category during the entire Bush administration were: 'money' (61 times), 
Figure 1 - 100 top words during George W. Bush's administration found in the Patterns of Global Terrorism and

in the Country Reports on Terrorism 2000-2007 (years of reference)

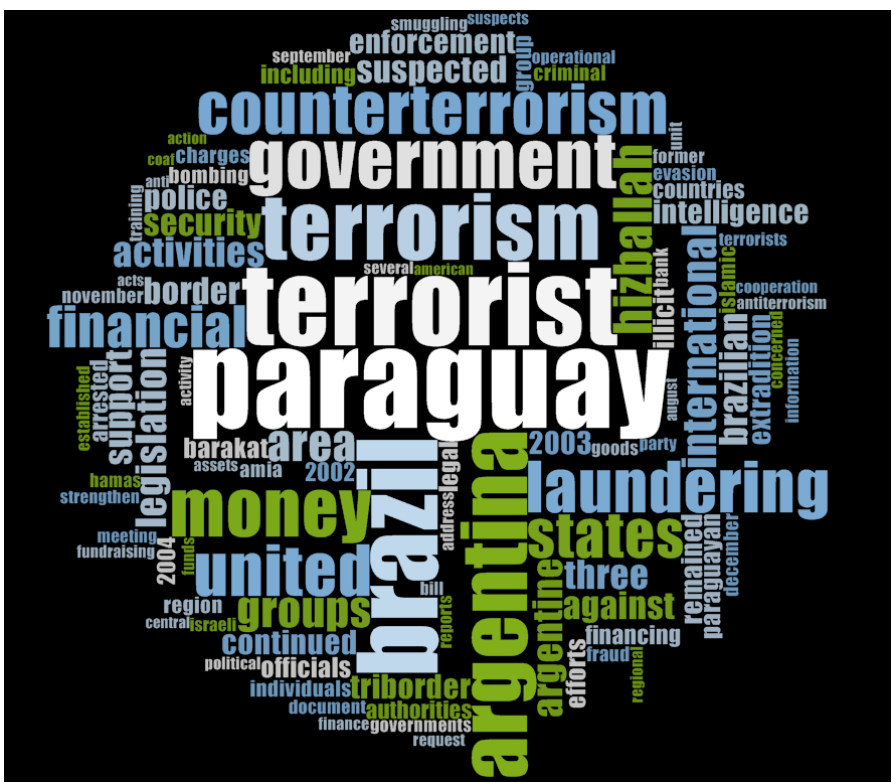

Source: Created by the author

Figure 2 - 100 top words during Barack Obama's administration found in the Country Reports on Terrorism 2008-2015 (years of reference)

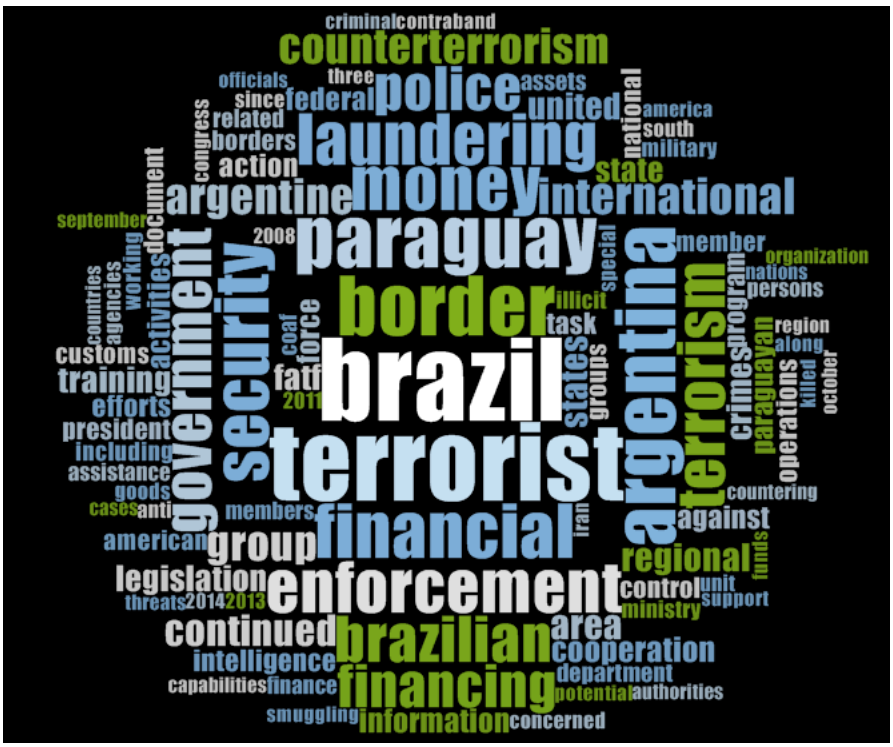

Source: Created by the author. 
which was the sixth most frequent word, 'laundering' (56), the seventh, 'financial' (45), the tenth, and 'financing' (19), $26^{\text {th }}$, as shown in Table 2 (see Appendix). During Obama's presidency, the top financial category words were: 'financial' (126), ranked fifth, 'money' (121), sixth, 'laundering' (114) eighth, 'financing' (95), thirteenth, and 'FATF' (48), 23 ${ }^{\text {th }}$, which are the initials of the Financial Action Task Force. These are also presented in Table 4 (see Appendix).

As the most frequent word of the financial semantic field by both administrations was 'money', the deployment of this word was closely checked. The recurrence peaked in the 2006 (17 times), 2007 (22) and 2008 (29) reports. In general, the use of 'money' relates to 'laundering' or 'launderer.' 'Laundering' is the ninth and eighth most frequent word in the two sets of excerpts, during Bush's (56 times) as well as in Obama's presidency (121 times). The first time both words are used together is in the 2001 edition of Patterns of Global Terrorism, deployed only three times. Then, 'laundering' appears again six times in the 2004 report. The frequency peak of this word also occurs in the documents between 2006 and 2008, exactly as with the word 'money'. After that, the recurrence begins to decrease gradually in the ranking. In 2009, 'laundering' was the fourth most used word (found 16 times); the seventh in 2010 (13) and in 2011 (15); the eighth in 2012 (10) and in 2013 (14); the eleventh in 2014 (9) and twelfth in 2015 (9) - as shown in Tables 1, 2, 3 e 4 (see Appendix).

Both 'money' and 'laundering' were more used in connection with Hizballah in the 2005 and 2007 reports, editions published in April 2006 and April 2008, during the Bush administration. This trend may have reflected a pressure against local governments in the months of tensions and of the preparations to the attacks of Israel to Lebanon in July/ August 2006 and in Gaza in December 2008/January 2009. After these three reports, direct relations between the two words and the group could not be detected in the subsequent documents. During Bush's administration, the word Hizballah was the eleventh most used, but its frequency fell during the next presidency, not reaching the top 100. As Israel is an important US ally in the Middle East, the two conflicts may have influenced the public demands of the US Department of State against supposed financing sources of both Hizballah and Hamas in South America.

There are two main hypotheses to explain the US Department of State focus on financial crimes in the Tri-Border Area. The first one suggests that it is an approach to constrain the local community from transferring money, especially to Lebanon. The US pressure to prevent local businessmen to send money abroad to buy products or send remittances to their families in Lebanon is expected to result in the withdraw of ideological support to Hizballah and Hamas (Nasser 2016). The second explanation is that the US strategy to focus on the financial sources of these groups in Latin America is closely directed by the lack of evidence concerning the existence of terrorist cells in the region (Villa 2020). Thus, the narrative of the Tri-Border Area as a strong source of terrorist financing would make the region susceptible for the securitization move by making the acceptance of the threat easier to local audiences. It seems that both explanations make sense, as they help us 
understand the main advantages for the USA regarding pressuring the local communities and governments.

After the 2004 edition, the reports related the word 'money' most notably to another subject: the legislative process of bills referring to terrorism financing in the three countries' national Congresses. It also included the enforcement of recommendations made by the Financial Action Task Force (FATF) and other international organizations to combat financial crimes, especially money laundering. This finding could contradict the initial hypothesis of an acute connection between the discourse on terrorism in the Tri-Border Area and the Middle Eastern actors. Nevertheless, it seems that the credibility of this link is key to secure the success of a securitization move. The need for this legislation was not an internal urgency, but rather a probable outcome from external pressure.

The 2007, 2008 and 2009 reports, for instance, mention the lack of effort of the Brazilian legislative to vote the anti-terrorism and anti-money laundering bills, that were pending since 2005 (Department of State [USA] 2007: 151). In 2007 and 2008, the US Congress discussed granting funds to the Southern Command (Ferreira 2009: 189), which may have increased the need to justify it. On the other hand, the reports from 2010 to 2014 are more subtle regarding this subject. In 2010, the Brazilian Chamber of Deputies passed an updated money laundering bill establishing stricter penalties, which probably relieved the anxiety revolving around the issue. However, the 2011 document stressed that 'a specific terrorist financing provision was not included' (Department of State [USA] 2011: 153).

The law that would deal with crimes related to terrorism would eventually be approved five years later, after the World Soccer Cup of 2014 yet before the 2016 Rio Olympics. President Dilma Rousseff signed the Law 13.260/2016 months before being impeached by the Brazilian National Congress. The law provides procedures for freezing assets relating to groups considered terrorists by the United Nations, such as Al Qaeda, Taliban, and Daesh (Department of State [USA] 2016: 274). The 2014 report described it as the end of a 'longstanding gap in Brazil's ability to confront terrorism financing' (Department of State [USA] 2015: 260). Rousseff was under the pressure of international organizations and security experts before the Olympic Games (Rötzsch 2011), an international competition that took place in Rio de Janeiro and would attract thousands of tourists and international attention. The law introduced new investigation and procedural measures and defined what a terrorist organization consists of (Aita 2017), but faced criticism by social and human rights movements, as well as by the local office of the United Nations High Commissioner for Human Rights (Benites 2016; Terenzi 2016). However, new arguments were also important to overthrow old barriers against the approval of such law. The need for protection against preparatory acts to commit a crime, for the recruiting of foreign terrorists and incitement to terrorism, especially in social media, would receive more attention than the previous arguments (France 2018: 310-311).

The reports also mention the cooperation efforts between the US authorities and local ones. The most common partnership are special courses 'ranging from interview and interrogation techniques, terrorist financing, and money laundering investigations' offered 
by the Americans (Department of State [USA] 2014: 259). The training courses attended by Brazilian officials are mentioned in the 2007, 2008, 2009, 2013 and 2014 reports; the Paraguayan ones, in the 2007 and 2009 reports. There is no mention of courses taught to Argentinian authorities. Interviews made in Foz do Iguaçu in 2018 have shown that most of the Polícia Federal and Receita Federal top officials had taken such courses in the USA (Castro 2020).

Not only the training courses to local police officials were important tools to implement the desired measures, but also to pressure politicians to change the legislation. The unsteady connection between 'money' - one of the most used words - and Hizballah, the term is found more attached to events concerning legislative and executive procedures of Brazil, Paraguay, and Argentina, indicating a different perspective concerning the interests of the US governments. It seems that the reports have a special focus on exerting pressure for change in the three countries' legislation concerning financial crimes related to terrorism, as well as for requesting the adoption of the FATF recommendations. In addition to Brazil, the two other Tri-Border countries approved new laws concerning terrorism in the analysed period. Argentina, the only of the three countries that suffered two terrorist attacks, had an antiterrorist law since 2000 (Aita 2017). New and reshaped laws were added in 2007 and 2011. The most important change was the replacement of the idea of 'terrorist illicit association' for 'terrorist act' to define the crime (Durrieu 2015; Aita 2017). Paraguay also approved anti-terrorism laws before Brazil. The country implemented new legislation in 2010 and 2011. The last one improved the capacity of the local courts to freeze assets to meet new demands of international organizations concerning the financial funding for terrorist groups.

Contrary to expectations, this study did not find significant use of words related to the semantic field of unlawful activities, a subject commonly linked to the Tri-Border Area. Words such as 'smuggling' and 'illicit' were not among the top 50 most detected words and the word 'drug' was not even in the top 100 list. This consists of additional evidence that seems to indicate that the focus of the reports was to highlight the financial activities in the region and urge scrutiny on this particular issue by the local authorities. The overall emphasis in the financial semantic field, as well as in the legislation concerning money laundering, linked the region with the US interests in the Middle East in many ways.

\section{Conclusions}

The Patterns of Global Terrorism and the Country Reports on Terrorism are public documents published not only to fulfil the requirement to periodically inform the US Congress but also to pressure other countries to adopt measures to combat the actions of terrorists and terrorism financing even in regions such as the Tri-Border Area, where no evidences of terrorist actions were provided. The main objective of this study has been to identify which connections were built between terrorism and the region during the administrations of Presidents Bush and Obama by analysing these documents. The main hypothesis is that the dynamics of the US relations with the Middle East - especially with Iran, 
Hizballah, and Hamas - direct the narratives and criticism of the reports. The findings of this study suggest that there is a special focus on these issues, despite the lack of evidence proving that both a link between them and the Tri-Border Area - and the need to address other security problems in the region - exist.

The hypothesis was confirmed as we could identify some parallels between an internalist and externalist view of the securitization concept. Events that occurred in the Middle East could be associated to the frequency rise of some words and demands. The most striking link between the Tri-Border reports and the Middle East events was the increased usage of the words 'money' and 'laundering' in the 2006, 2007 and 2008 reports, released in the years 2007, 2008 and 2009, respectively. These documents were published during and after the wars between Israel and Lebanon (2006) and the Gaza War (20082009). The connection between the words 'Hizballah' and 'money laundering' were mostly found in the 2005, 2006 and 2007 reports, respectively released in 2006, 2007 and 2008.

The emphasis placed on the financial semantic field by both administrations, especially on money laundering during these specific periods, may reveal a strong connection between the interests of the US in the Middle East and the discourse about the Tri-Border Area. Therefore, these findings indicate that there is a direct impact between what happens in the Middle East and what the US Department of State writes about this South American frontier. However, the most striking feature of this rhetoric is the missing link that would prove that illegal money from the Tri-Border Area is financing terrorist acts. The focus on the repetition of the accusations against the three countries may be a way to hide the lack of this important piece of evidence that should be displayed by the US Department of State. It may be used to promote the view that Hizballah is an international terrorist group that operates in other parts of the world rather than a local defence militia against Israeli offensives in Lebanon.

Likewise, the frequent mentions of legislative procedures concerning antiterrorism bills show that there is a consistent interest of the securitizing actor in making this connection to securitize the Tri-Border Area. Countries such as Brazil and Paraguay, which had no recent problems with terrorism, approved anti-terrorist laws that were not raised by popular demand, but rather, by an external pressure. The Brazilian law was voted and approved months before the arrival of foreign tourists to the Rio Olympic Games to comply with the security concerns from countries such as USA and Israel. The Brazilian and Paraguayan national Congresses can be seen as audiences that accepted the need for special measures to combat the terrorist threat, but both took actions inside the normative framework. It is not possible to determine that the direct pressure of the securitizing actors resulted in this movement. Rather, this was probably one of the dynamics that promoted the approval of the new measures.

On the other hand, it can be argued that Argentina had enough reasons to implement new laws tackling terrorist acts, as the country was the target of two bombings in the 1990s. However, most of these laws were approved more than a decade after the Buenos Aires attacks and years following September $11^{\text {th }}$, that is, only in 2007 and 2011. This fact may also imply that other kinds of pressures or contexts were more decisive to the 
implementation of the new legislation. Other actors such as FATF and internal forces may have helped to increase the tension and to approve such laws in the three countries. That is why we may assume that there was also a security movement, but it is likewise not possible to trace connections only and directly to a specific US demand.

What the study clarifies is that there were continuous securitizing movements during most of these 16 years of documents. These were not completely successful in Argentina, Brazil, and Paraguay, as the measures were taken inside the normal bounds of political procedure, despite the fact that most of these laws took more than a decade to be approved. A further study could reveal the impacts of anti-terrorism laws, like the ones approved in the three countries. It would also help us to understand why these were so important to the US Department of State discourse. If the debate is to be moved forward, a better understanding of the use of these new laws is also suggested, especially to verify if they made requests to facilitate the acceptance of the extradition of foreign residents by local courts. New outcomes in the securitization of the Tri-Border Area may also develop soon, as both Argentina and Paraguay recently declared Hizballah a terrorist group, and as the Brazilian President Jair Bolsonaro announced in August 2019 his intention to follow suit. The benefits or the inconveniences of these decisions are also yet to be disclosed.

\section{Notes}

1 For example, the September $11^{\text {th }}$ attacks are in the 2001 edition of the Patterns of Global Terrorism, published in 2002. The edition of the Country Report on Terrorism that refers to the last year of Obama's administration, namely 2016, was published in 2017, during the first year of Donald Trump's presidency. Therefore, this one is not included in this corpus.

2 In this article, we spell Hizballah in the same format the PGT and CRT reports do. Yet, when we quote other authors who use a different spelling like Hezbollah e Hizbullah, their choice is respected.

3 Four days after filing the complaint, Nisman was found dead with a gunshot wound to the head, in suspicious circumstances.

4 Nisman's complaint was not accepted by the tribunal, even after an appeal made by a new prosecutor.

5 In 2001, SIDE changed its name to Secretaría de Inteligencia (SI), but it was still viewed as too attached to the old military regime. In 2015, President Cristina de Kirchner dismissed SI and created the Agencia Federal de Inteligencia following the death of Nisman. She claimed that the act was a 'debt to democracy' (Iñurrieta 2015).

6 It refers to Brazil, Sudan, Yemen and Malaysia - countries to which he travelled before the attacks.

7 The report referred to the year 2000, the last year of the Clinton administration which was also included because it was published on 30 April 2001, during Bush's first year as a president. The same measure was taken concerning the next president: the report referred to the year 2008, period in which Bush was still president; it was included in the analysis as belonging to the Obama administration, as it was published in 2009, after he took office.

8 The designation Tri-Border Area is found in the Patterns of Global Terrorism reports as Tri-Border or Triborder. In this paper, it is reproduced as it is written in these documents. 


\section{References}

Adghirni, S. 2012. 'O fugitivo iraniano.' Folha de S. Paulo [online], 21 October. At http://www1.folha.uol.com.br/fsp/mundo/73239-o-fugitivo-iraniano.shtml [Accessed on 20 March 2015].

Aita, E. 2017. 'A Tríplice Fronteira sul sob a ótica do terrorismo: uma análise da legislação antiterrorismo da Argentina, Brazil e Paraguai'. Estudos Internacionais 4 (2): 35-56.

Amaral, A B. 2010. A Tríplice Fronteira e a Guerra ao Terror. Rio de Janeiro: Apicuri.

Benites, A. 2016. 'Sob pressão internacional, Câmara aprova lei que tipifica o terrorismo.' El País Brasil [online], 25 February. At http://brasil.elpais.com/brasil/2016/02/24/politica/1456351659_569702. html [Accessed on 23 June 2019].

Benson, T. 2003. 'Tríplice Fronteira quer acabar com imagem ligada ao terrorismo.' Reuters, 11 April. At https://noticias.uol.com.br/inter/reuters/2003/04/11/ult27u34010.jhtm [Accessed on 23 June 2019].

Buzan, B, O Wæver and J de Wilde. 1998. Security. A New Framework for Analysis. Boulder: Lynne Rienner.

Caballero, R. 2005. Amia: la verdade imposible. Buenos Aires: Sudamerica.

Castro, I C S de. 2015. 'O governo Barack Obama, a Tríplice Fronteira e o terrorismo: um estudo de caso' Paper delivered at $39^{\circ}$ Encontro Anual da Anpocs, Caxambu, Brazil. At http://www.anpocs.org/ portal/index.php?option $=$ com_docman\&task=doc_view\&gid=9717\&Itemid $=461$ [Accessed on 1 March 2016].

. 2020. 'Contestando a Guerra ao Terror: as respostas brasileiras às suspeitas de terrorismo.' In M A Silva and I C S de Castro. Além dos Limites: a Tríplice Fronteira nas Relações Internacionais Contemporâneas. Manuscript submitted for publication.

Costa, T G and G H Schulmeister. 2007. 'The Puzzle of the Iguazu Tri-Border Area: Many Questions and Few Answers Regarding Organized Crime and Terrorism Links.' Global Crime (8) 1:26-39.

CNN [online]. 2003. 'Police: Mohammed visited Brazil in 1995.' 6 March. At http://www.state.gov/t/ isn/ecc/c27911.htm [Accessed on 3 July 2015].

Davies, W. 2015. 'Quem matou Alberto Nisman?' BBC Brazil [online], 29 May. At http://www. bbc.com/portuguese/noticias/2015/05/150529_quem_matou_alberto_nisman_argentina_lgb [Accessed on 2 March 2018].

Department of State [USA]. 1997. Patterns on Global Terrorism 1996. At https://1997-2001.state. gov/global/terrorism/1996Report/1996index.html [Accessed on 5 March 2018].

. 2001. Patterns on Global Terrorism 2000. At https://www.state.gov/j/ct/rls/crt/2000/ [Accessed on 5 January 2014].

. 2002. Patterns on Global Terrorism 2001. At https://www.state.gov/documents/organization/10286.pdf [Accessed on 5 January 2014].

2003. Patterns on Global Terrorism 2002. At: https://www.state.gov/documents/organization/20177.pdf [Accessed on 5 January 2014].

. 2004. Patterns on Global Terrorism 2003. At https://www.state.gov/documents/organization/31912.pdf [Accessed on 5 January 2014].

2005. Country Reports on Terrorism 2004. At https://www.state.gov/j/ct/rls/crt/c14818.htm [Accessed on 5 January 2014]. 
. 2006. Country Reports on Terrorism 2005. At https://www.state.gov/j/ct/rls/crt/2005/64330. htm [Accessed on 5 January 2014].

. 2007. Country Reports on Terrorism 2006. At https://www.state.gov/j/ct/rls/crt/2006/ [Accessed on 5 January 2014].

2008. Country Reports on Terrorism 2007. At http://www.state.gov/j/ct/rls/crt/2007/index. htm [Accessed on 5 January 2014].

. 2009. Country Reports on Terrorism 2008. At http://www.state.gov/j/ct/rls/crt/2008/index. htm [Accessed on 5 January 2014].

. 2010. Country Reports on Terrorism 2009. At http://www.state.gov/j/ct/rls/crt/2009/index. htm [Accessed on 5 January 2014].

. 2011. Country Reports on Terrorism 2010. At http://www.state.gov/j/ct/rls/crt/2010/ [Accessed on 5 January 2014].

2012. Country Reports on Terrorism 2011. At http://www.state.gov/j/ct/rls/crt/2011/ [Accessed on 5 January 2014].

2013. Country Reports on Terrorism 2012. At http://www.state.gov/j/ct/rls/crt/2012/ [Accessed on 5 January 2014].

2014. Country Reports on Terrorism 2013. At http://www.state.gov/j/ct/rls/crt/2013/ [Accessed on 20 May 2015].

2015. Country Reports on Terrorism 2014. At http://www.state.gov/j/ct/rls/crt/2014/ [Accessed on 20 May 2015].

2016. Country Reports on Terrorism 2015. At http://www.state.gov/j/ct/rls/crt/2015/ [Accessed on 2 July 2017].

Devia-Garzon, C A and D A Ortega-Avellaneda. 2019. 'Características y desafíos del crimen organizado transnacional en la Triple Frontera: Argentina-Paraguay-Brasil.' Revista Criminalidad 61 (1): 9-28.

Durrieu, R. 2015. 'Ley antiterrorismo: una muestra más de la expansión injustificada y abusiva del derecho punitivo.' Revista del Colegio de Abogados de la Ciudad de Buenos Aires [online] 75 (1): 9-26.

Ferreira, M A F S. 2009. 'A guerra global contra o terrorismo na América Latina: a Tríplice Fronteira Argentina, Brasil e Paraguai como uma ameaça à segurança dos Estados Unidos?' In Luis Fernando Ayerbe (ed), De Clinton a Obama: política dos Estados Unidos para a América Latina. São Paulo: Editora Unesp, pp. 175-194.

2016. Combate ao Terrorismo na América do Sul. Uma análise comparada das políticas do Brasil e dos Estados Unidos para a Tríplice Fronteira. Curitiba: Editora Prismas.

Folch, C. 2012. 'Trouble on the Triple Frontier.' Foreign Affairs [online], 6 September. At http://www. foreignaffairs.com/articles/138096/christine-folch/trouble-on-the-triple-frontier [Accessed on 12 December 2014].

France, G J. 2018. As Origens da Lei Antiterrorismo no Brasil. Belo Horizonte: Editora Letramento.

Halliday, F. 2002. 'A new global configuration.' In T Dunne and K Booth (eds), Worlds in Collision: Terror and the Future of Global Order. New York: Palgrave, pp. 235-241.

Interpol. 2009. 'El Reda, Samuel Salman, wanted by the Judicial Authorities of Argentina.' At https:// www.interpol.int/es/notice/search/wanted/2009-19958 [Accessed on 15 February 2018]. 
Iñurrieta, S. 2015. 'Cristina anunció la disolucion de la ex-SIDE para atenuar el impacto de la crisis por caso Nisman.' El Cronista [online], 27 January. At https://www.cronista.com/economiapolitica/Cristina-anuncio-la-disolucion-de-la-ex-SIDE-para-atenuar-impacto-de-la-crisis-por-casoNisman-20150127-0065.html [Accessed 10 September 2019].

Jorge, B W G A. 2009. 'A presença militar dos Estados Unidos na América Latina: 1993-2009.' In Luis Fernando Ayerbe (ed), De Clinton a Obama: política dos Estados Unidos para a América Latina. São Paulo: Editora Unesp, pp. 69-92.

Karam, J T. 2013. 'The Lebanese Diaspora at the Tri-Border and the Redrawing of South American Geopolitics, 1950-1992.' Mashriq \& Mahjar: Journal of Middle East and North African Migration Studies 1 (1): 55-84.

Kollman, R. 2016. 'El prófugo equivocado.' Pagina 12 [online], 12 September. At https://www.pagina12.com.ar/diario/elpais/1-309692-2016-09-18.html [Accessed on 1 March 2018].

McCrisken, Trevor. 2011. 'Ten Years On: Obama's War on Terrorism in Rhetoric and Practice.' International Affairs [online] 87 (4): 781-801. At http://www.jstor.org/stable/20869759 [Accessed on 23 June 2019].

Ministry of Foreign Affairs [Brazil]. 2001. 'Cable No. 42174. Terrorismo. Fronteira Tríplice.' 1 November. At http://www.consultaesic.cgu.gov.br/busca/dados/Lists/Pedido/Attachments/588465/ RESPOSTA_PEDIDO_27-NUP09200000714201792-Rubens\%20Soares.pdf [Accessed on 26 October 2018].

Nasser, S. 2016. 'O Hezbollah e o dólar'. Revista Brasileiros, 21 May.

. 2018. 'A fronteira e o não lugar do terrorismo.' In L Scherer, F H L Goulart and P A F Veloso (eds), Brasil - Líbano. Legado e Futuro. Brasília: Funag, pp. 121-145.

National Commission on Terrorist Attacks upon the United States (NCTA). 2004. 'The 9/11 Commission Report.' At http://www.9-11commission.gov/report/911Report.pdf [Accessed on 10 August 2015].

Pinto, P H R. 2016. 'Conversion, Revivalism and Tradition: the Religion Dynamics of Muslim Communities in Brazil.' In M Narbona and P H R Pinto (eds), Crescent over Another Horizon: Islam in Latin America, the Caribbean and Latino USA. Austin: University of Texas Press, pp. 107-142.

Pinto, P H R and S Montenegro. 2008. 'As Comunidades Muçulmanas na Tríplice Fronteira: Identidades Religiosas, Contextos Locais e Fluxos Transnacionais.' Paper delivered at $26^{a}$ Reunião Brasileira de Antropologia, Porto Seguro, Brazil.

Policarpo Junior. 2003. 'Ele esteve no Brazil.' Veja. São Paulo, 1 March.

Rabossi, F. 2004. Nas ruas de Ciudad del Este: vidas e vendas num mercado da fronteira. PhD Thesis, Universidade Federal do Rio de Janeiro, Brazil.

Rivarola, A. 2020. 'Una millonaria coima para “importar” palestinos en la época de Stroessner.' ABC Color [online], 12 August. At https://www.abc.com.py/nacionales/2020/08/12/una-millonaria-coima-para-importar-palestinos-en-la-epoca-de-stroessner/ [Accessed on 12 August 2020].

Rötzsch, R. 2011. 'Brasil tem de se preocupar com terrorismo, diz perito.' Folha de S. Paulo [online], 21 April. At https://www1.folha.uol.com.br/fsp/esporte/fk2104201120.htm [Accessed on 20 August 2019].

Salinas, J J. 1997. Amia: el atentado. Quiénes son los autores y por qué no están presos. Buenos Aires: Planeta. 
Sanz, C and F Paolella. 2007. Amia. La gran mentira oficial. Buenos Aires; Trans Move. At http:// www.trans-move.com/Books/Files/ltifhy4voinlgfxjawdjgsqw_132857216.pdf [Accessed on 28 February 2018].

Stritzel, H. 2007. 'Towards a Theory of Securitization: Copenhagen and Beyond.' European Journal of International Relations 13 (3): 357-383.

Terenzi, G. 2016. 'ONU critica aprovação do projeto da Lei Antiterrorismo pelo Congresso.' Folha de S. Paulo [online], 22 February. At http://www1.folha.uol.com.br/poder/2016/02/1743863-onu-critica-aprovacao-do-projeto-da-lei-antiterrorismo-pelo-congresso.shtml [Accessed on 12 August 2019].

Tomás, A. 2019. 'AMIA: el segundo juicio contra Carlos Telleldín avanza a paso lento. Perfil [online], 17 July. At https://www.perfil.com/noticias/politica/amia-el-segundo-juicio-contra-telleldin-avanza-a-paso-lento.phtml [Accessed on 1 June 2020].

United States Code. n.d. 'Title 50 - War and National Defense, Chapter 56 - Export Administration, $\$ 4605$ Foreign Police Controls.'At http://uscode.house.gov/view.xhtml?path=/prelim@title50/ chapter56\&edition=prelim [Accessed on 26 February 2018].

Villa, R D. 2020. Prefácio: as várias imagens da Tríplice Fronteira. In S A Silva and I C S de Castro. Além dos Limites: a Tríplice Fronteira nas Relações Internacionais Contemporâneas. Manuscript submitted for publication.

Wikileaks [online]. 2009. 'Brazil: scene setter for October 27-30 visit of special rep of the president for non-proliferation-amb burk.' United States Embassy in Brazil, 23 October. At https://wikileaks. org/plusd/cables/09BRASILIA1261_a.html> [Accessed on 1 September 2015].

\section{Acknowledgements}

I would like to thank Rafael Duarte Villa, Janina Onuki, Thiago Babo, Ignacio Cardone, Micael Alvino da Silva, Marcelino Teixeira Lisboa, Mamadou Alpha Diallo and Heloisa Marques Gimenez for the comments and suggestions regarding a previous version of this paper and the two peer reviewers. This study was funded by FAPESP. Grants numbers: 2016/12824-6 and 2018/06825-5.

\section{About the author}

Isabelle Christine Somma de Castro is a FAPESP Postdoctoral Fellow in the Department of Political Science at the University of São Paulo (USP). She is a member of the Center for Research of International Relations (Nupri-USP), the National Institute of Science and Technology for Studies of the USA (INCT-Ineu) and the Triple Frontier and International Relations Research Center (GTF/Unila). She holds an M.A. and a Ph.D. from the University of São Paulo (USP). She was a visiting student at the Faculty of Asian and Middle Eastern Studies at the University of Cambridge with a Capes fellowship and a visiting Scholar in the Arnold A. Saltzman Institute of War and Peace Studies at Columbia University, with a FAPESP fellowship. 


\section{A Securitização da Tríplice Fronteira entre Argentina, Brasil e Paraguai}

Resumo: O objetivo deste estudo é identificar as principais características do discurso dos EUA em relação à Tríplice Fronteira entre Argentina, Brasil e Paraguai através da análise de 16 edições dos relatórios Patterns Global Terrorism e Country Reports on Terrorism, publicados entre 2001 e 2016. A teoria da Securitização é aplicada para explicar o uso dos atos de fala como movimentos para securitizar a região. Depois de utilizar o NVivo para medir a frequência das palavras, pôde ser observada uma forte ligação entre a ascensão do campo semântico financeiro e os confrontos no Oriente Médio. Também pôde ser observado que os relatórios revelam uma ênfase especial em relação à legislação sobre terrorismo nos três países mencionados.

Palavras-chave: Tríplice Fronteira; securitização; análise de conteúdo; terrorismo; George W. Bush; Barack Obama.

Received on 14 October 2019 and approved for publication on 13 July 2020.

\section{(c)) BY-NC}

https://creativecommons.org/licenses/by-nc/4.0/ 


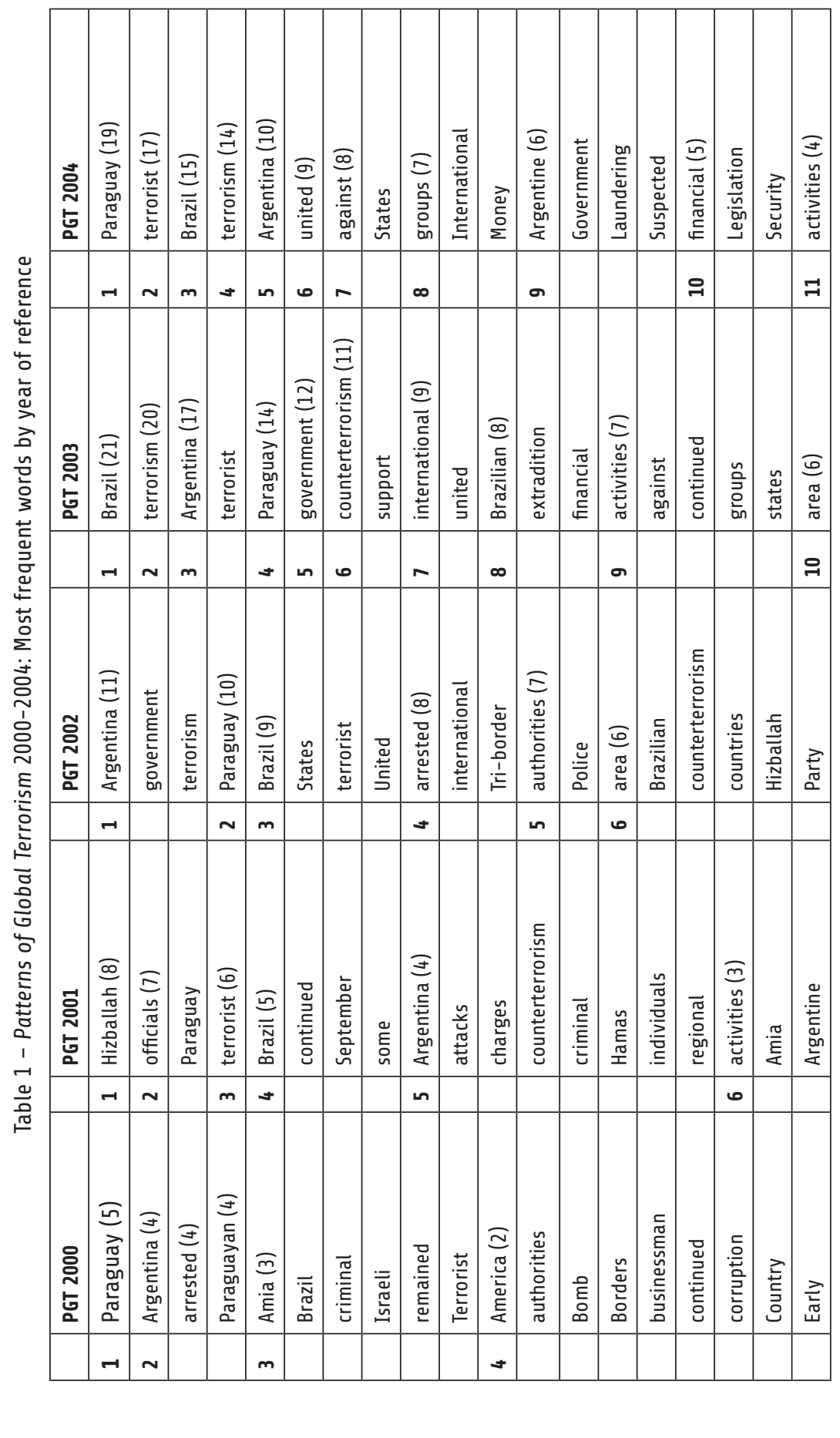




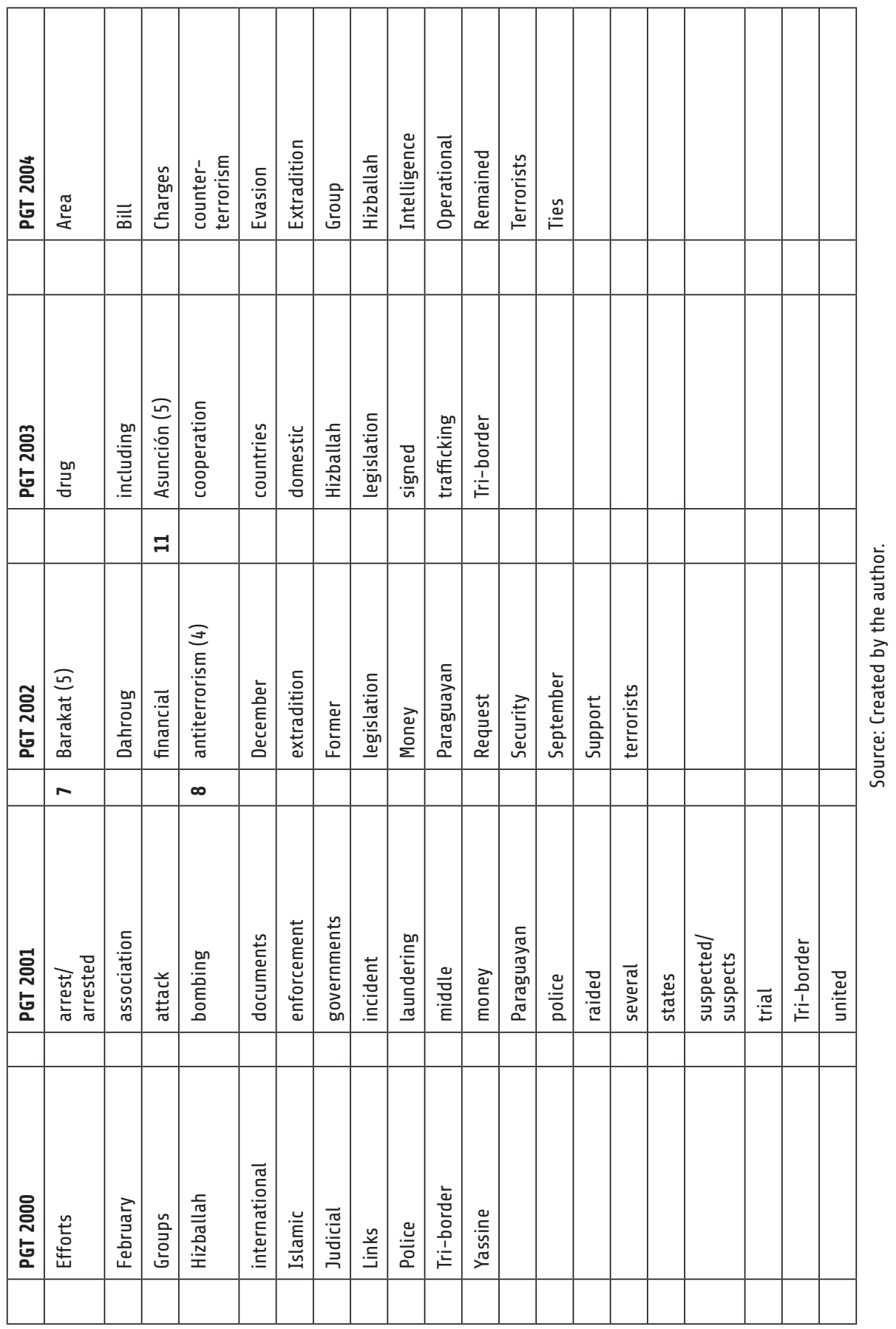




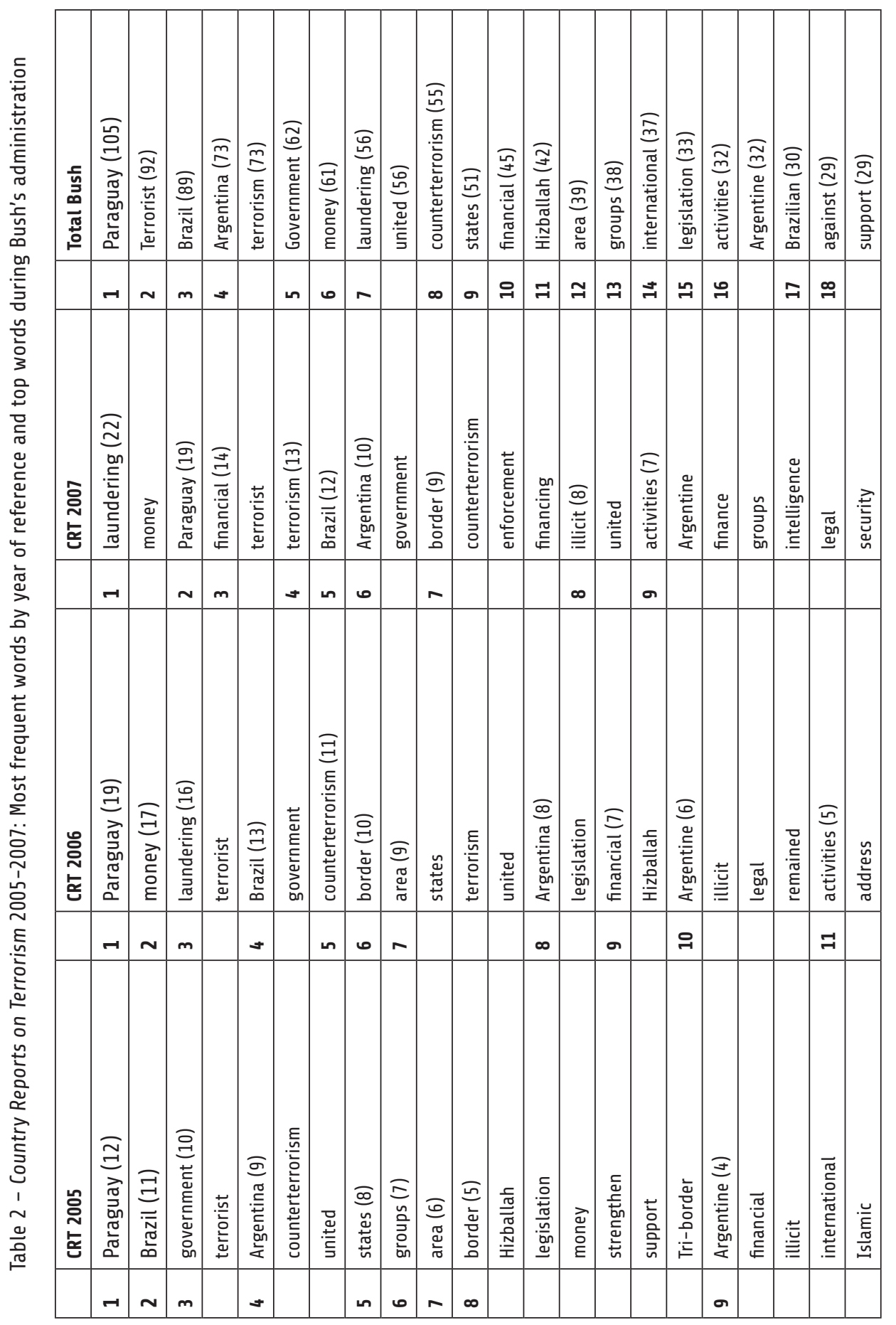




\begin{tabular}{|c|c|c|c|c|c|c|c|c|c|c|c|c|c|c|c|c|c|c|c|c|c|c|}
\hline 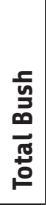 & 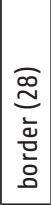 & 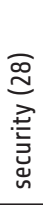 & 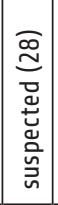 & 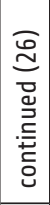 & 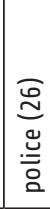 & 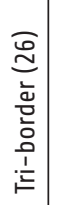 & 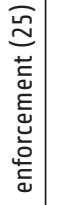 & 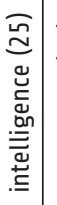 & 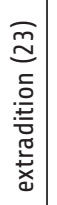 & 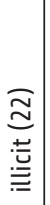 & 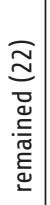 & 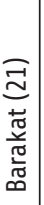 & 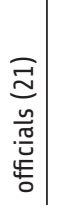 & 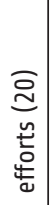 & 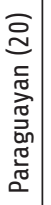 & 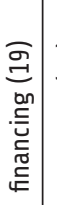 & 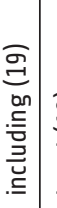 & 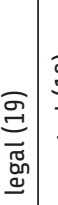 & 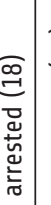 & 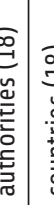 & & 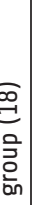 \\
\hline & 9 & & & సి & & & $\approx$ & & $\approx$ & $\approx$ & & $\approx$ & & $\approx$ & & $\stackrel{\sim}{\sim}$ & & & $\approx$ & & & \\
\hline 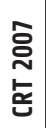 & 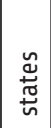 & 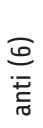 & $\frac{\pi}{\frac{\pi}{\pi}}$ & 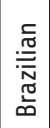 & 壳 & 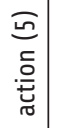 & 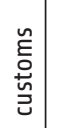 & 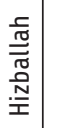 & 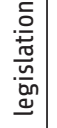 & 然 & & & & & & & & & & & & \\
\hline & & ㅇ & & & & $\Rightarrow$ & & & & & & & & & & & & & & & & \\
\hline
\end{tabular}

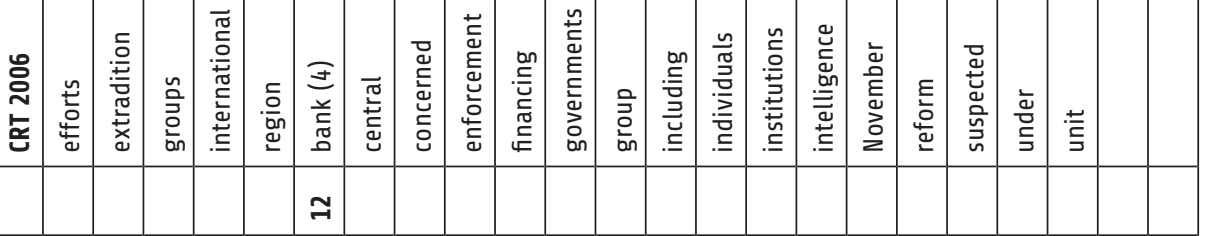

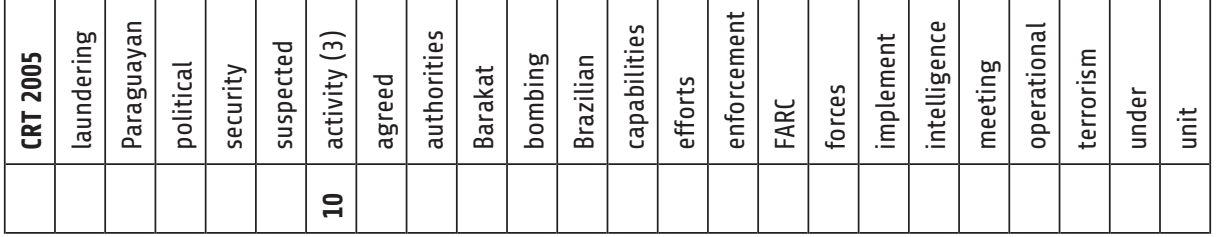




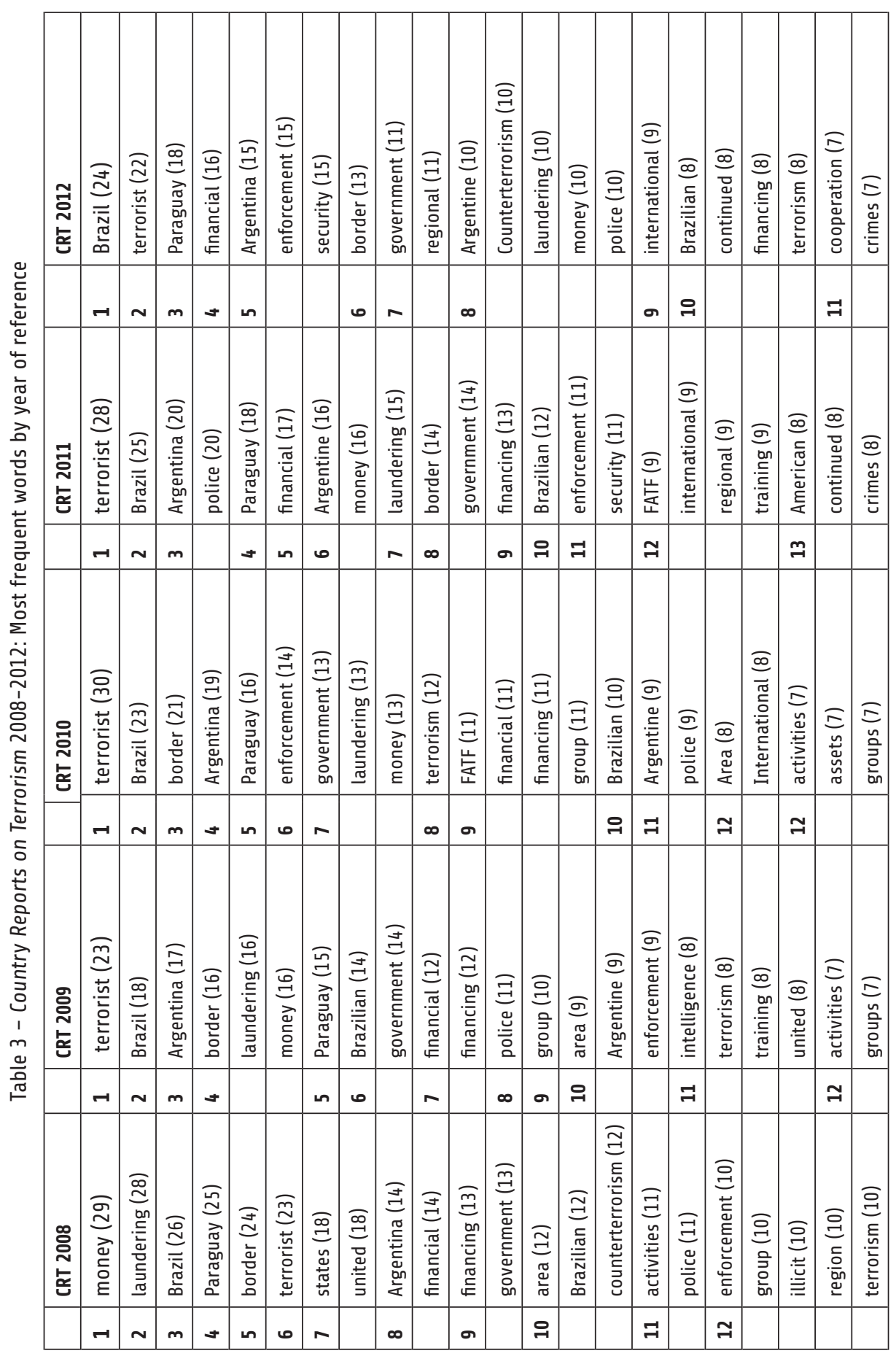




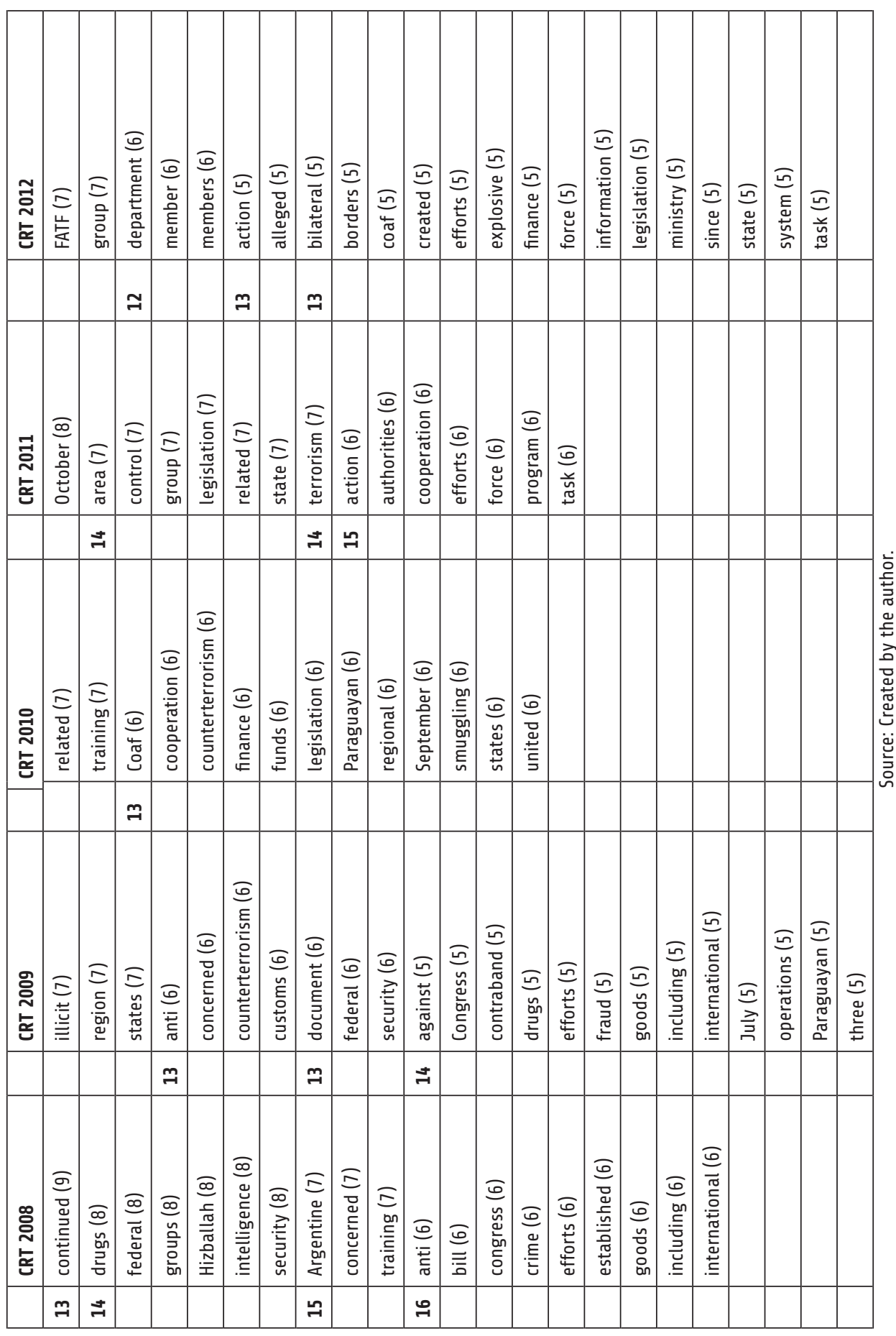




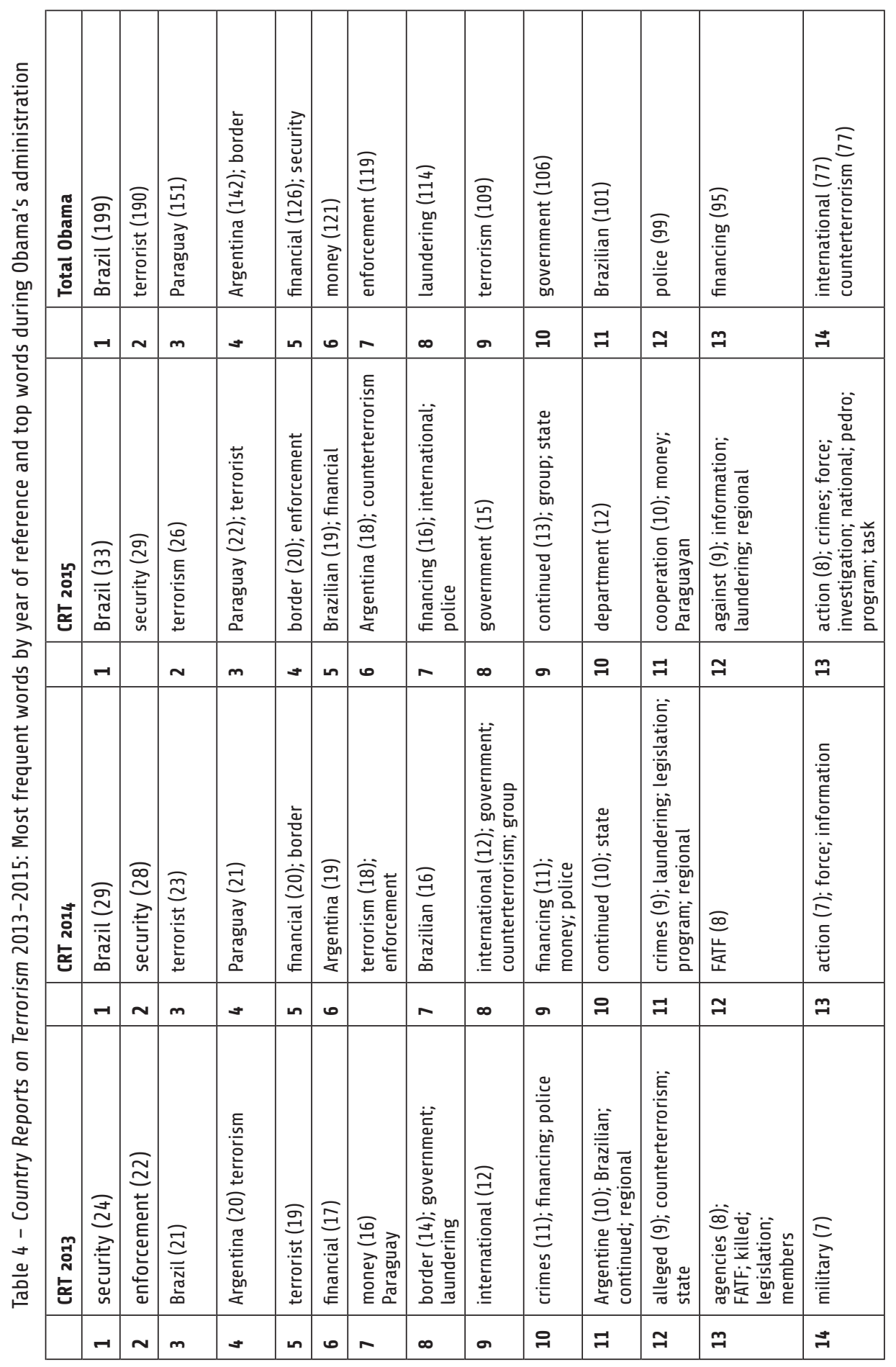




\begin{tabular}{|c|c|c|c|c|c|c|c|c|c|c|c|c|c|c|c|c|c|c|c|}
\hline 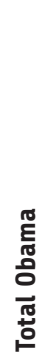 & 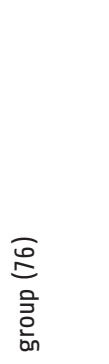 & 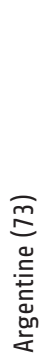 & 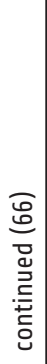 & 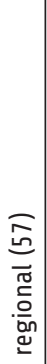 & 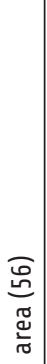 & 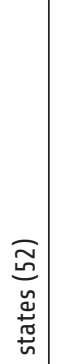 & 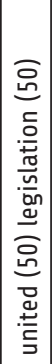 & 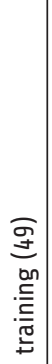 & 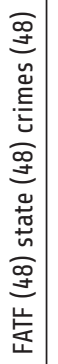 & 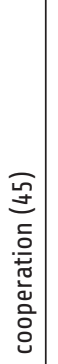 & 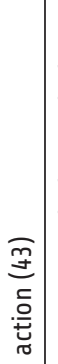 & 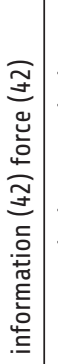 & 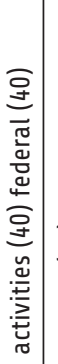 & 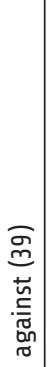 & 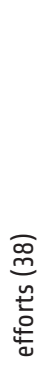 & 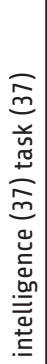 & 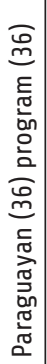 & 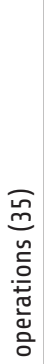 & 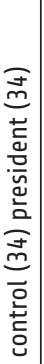 \\
\hline & உ & $\stackrel{्}{\longrightarrow}$ & न & $\stackrel{\infty}{\sim}$ & I) & 이 & $\vec{N}$ & $\approx$ & $\tilde{\sim}$ & $\approx$ & $\stackrel{\sim}{\sim}$ & $\stackrel{\sim}{\sim}$ & $\approx$ & $\stackrel{\infty}{\sim}$ & వి & 이 & $\vec{m}$ & $\approx$ & $\mathfrak{m}$ \\
\hline 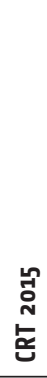 & 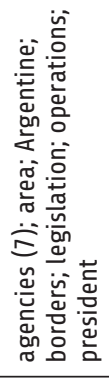 & & & & & & & & & & & & & & & & & & \\
\hline & $\vec{H}$ & & & & & & & & & & & & & & & & & & \\
\hline $\begin{array}{l}\text { ज्ञ } \\
\text { N̦ }\end{array}$ & 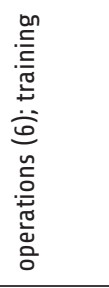 & 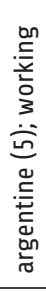 & & & & & & & & & & & & & & & & & \\
\hline & $\vec{\Rightarrow}$ & $\bumpeq$ & & & & & & & & & & & & & & & & & \\
\hline $\begin{array}{l}\text { m. } \\
\text { N } \\
\text { 온 }\end{array}$ & 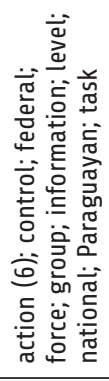 & & & & & & & & & & & & & & & & & & \\
\hline & $\stackrel{n}{\sim}$ & & & & & & & & & & & & & & & & & & \\
\hline
\end{tabular}

